\title{
Effect of Tricho-compost against Seedling Blight Disease of Wheat Caused by Sclerotium rolfsii
}

\author{
M. lqbal Faruk* \\ Plant Pathology Division Bangladesh Agricultural Research Institute Joydebpur, Gazipur-1701, Bangladesh
}

Received: February 8, 2018 / Revised: July 8, 2018 / Accepted: August 31, 2018

\begin{abstract}
The efficacy of formulated Trichoderma harzianum-based Tricho-compost, seed treatment with Trichoinocula, and chemical fungicide Provax $200 \mathrm{WP}$ against foot and root rot diseases of wheat caused by Sclerotium rolfsii was tested in the pot house and in the research field of Plant Pathology Division, Bangladesh Agricultural Research Institute, Gazipur, Bangladesh. Tricho-compost was prepared with a mixed substrate of cow dung, rice bran, and poultry refuse colonized by T. harzianum. Seedling mortality of wheat was significantly reduced by the Tricho-compost, Tricho-inocula, and Provax $200 \mathrm{WP}$ both in the pot house as well as in the field experiments. The yield of wheat was sharply increased over the control due to the $T$. harzianum formulations and Provax $200 \mathrm{WP}$. Among the treatments, soil application of Tricho-compost was more efficient in reducing seedling mortality and accelerating plant growth with an increased yield of wheat with $S$. rolfsii-inoculated pot cultures and field experiments.
\end{abstract}

Keywords: Trichocompost, Trichoderma harzianum, Tricho-inocula, Sclerotium roflsii, seedling blight, wheat

\section{Introduction}

Wheat (Triticum aestivum L.) is considered as one of the most important cereal crops in the world and it became to the second most important cereal crop after rice in Bangladesh. The average yield of this crop is only $2.60 \mathrm{t} / \mathrm{ha}$ in Bangladesh [1]. The average yield of wheat in Bangladesh is lower in comparison to other countries. Diseases play an important role in lower yield of wheat in the country. Wheat is attacked by at least 20 different diseases in Bangladesh [2, 3], of which five are considered as major diseases, they are Bipolaris leaf blightBpLB (Bipolaris sorokiniana), leaf rust (Puccinia recondita), seedling blight (Bipolaris sorokiniana), foot and root rot (Sclerotium rolfsii Tode) and black point (B. sorokiniana, Alternaria alternata $(\mathrm{Fr})$ Keissler, Curvularia

\section{*Corresponding author}

Tel: +88-02-9294065, Fax: +88-02-49261415

E-mail: mifaruk2012@yahoo.com

๑ 2018 , The Korean Society for Microbiology and Biotechnology lunata (Wakker) Boedijn and a species of Fusarium. S. rolfsii, an omnivorous, soil-borne fungal pathogen, causes disease on a wide range of agricultural and horticultural crops.

Management of this pathogen through conventional method such as physical, cultural etc. is difficult. The use of chemicals has been found effective in controlling fungal diseases of plant, but chemical control using fungicides required large amount which made health hazardous to grower and pollution of environment and soil. Public concern with fungicide residues, as well as pathogen resistance to some pesticides, has increased the need to find alternative methods for protection of crops against the diseases $[4,5]$. Thus, biological control using antagonistic microbes alone, or as supplements to minimize the use of chemical pesticides in a system of integrated plant disease management, has become more important in recent years [6]. Many studies have shown that biological control offers an environmentally friendly alternative method for soil-borne pathogens [7, 8]. Vari- 
ous fungal species have been used as biological agents that effectively control plant diseases, and about $90 \%$ of such bio-control agents are different strains of $T$. harzianum, T. virens, T. viride [9]. The effect of $T$. harzianum as bio-agent against $S$. rolfsii and F. oxysporum was reported by many investigators $[10,11]$. $T$. harzianum has been identified as potential biocontrol agents for the management of various plant diseases including seedling diseases caused by several plant pathogenic fungi [12-14]. Trichoderma spp. have been reported to compete for nutrients and space, secrete antifungal compounds, parasitize fungal pathogens, and induce systemic resistance in the host plant $[15,16]$. T. harzianum is commercially used as a preventive measure for several soil borne plant pathogenic fungi $[11,17]$. The mass production of Trichoderma on solid substrates promotes the synthesis of enzymes which help in its bio-control mechanism [18].

The utilization of large number of agro-wastes as substrates, use of wide variety of materials, low capital involvement and potential higher volumetric productivity etc. are necessary to promote Trichoderma. Many researchers have been used cost effective substrates like wheat bran, rice bran, maize bran, sawdust [19]; rice straw, chickpea bran, grass pea bran, rice course powder, black gram bran [20]; cow dung, poultry manure, ground nut shell, black ash, coir waste, spent straw from mushroom bed, talc, vermiculite [21], sewage sludge compost [22]. So, mass production of T. harzianum on comparatively cheap, stable and easily available substrate is essential. Yet information on mass production of $T$. harzianum to control seedling disease of wheat is inadequate under Bangladesh condition. Therefore, the present study was aimed to find out a suitability of solid substrate for mass production of Tricho-compost with $T$. harzianum and also its inocula for seed treatment to reduce foot and root rot disease caused by $S$. rolfsii Sacc. of wheat.

\section{Materials and Methods}

The performance of Tricho-inocula (T. harhianum), Tricho-composts and Provax 200 WP in controlling foot and root rot disease of wheat caused by Sclerotium rolfsii was investigated both in pot culture for one season during $2012-13$, and in the field experiments at three cropping seasons during 2013-14, 2014-15 and 201516. Previously, seventy two isolates of T. harzianum were obtained from different location of Bangladesh and their efficacy was tested against different soil borne pathogens including $S$. rolfsii in the laboratory. Few isolates of T. harzianum including TM7 were found more vigorous to suppress the soil borne pathogens including S. rolfsii. A pure culture of T. harzianum (TM7) was grown in potato dextrose agar (PDA) medium which was used to formulate in the substrates.

\section{Tricho-compost preparation}

Isolated T. harzianum (TM7) was initially multiplied on substrate containing a mixture of rice bran, wheat bran and mustard oilcake to obtain a formulated T. harzianum. The formulated T. harzianum was used for mass multiplication in two different mixtures of cow dung based compost materials. One of those composts contained cow dung and rice bran and the other contained a mixture of cow dung, rice bran and poultry manure and these composts were designated as Tricocompost-1 and Trico-compost-2, respectively. The formulated $T$. harzianum was added in between two layers of compost materials and kept for $45-50$ days maintaining the moisture content approximately $60-70 \%$ for rapid multiplication of $T$. harzianum in the compost materials.

Pathogenic fungal inocula preparation: The pure cultures of the pathogenic fungi $S$. rolfsii was prepared on PDA medium. The inoculum of $S$. rolfsii was multiplied separately on a mixture of wheat bran, khesari bran and mustard oilcake (MOC).

\section{Seed treatment}

The T. harzianum was cultured in PDA and potato dextrose broth (PDB) media and the spores were harvested from 10 days old culture separately. The seeds of wheat (var. BARI Gom 26) were treated with the spore suspension of $T$. harzianum maintaining the approximate spore concentration of $1 \times 10^{8} / \mathrm{ml}$. Similarly another set of seeds were also treated with Provax 200 WP (Carboxin + Thiram $37.5 \% \mathrm{WS})$ at $2.5 \mathrm{~g} / \mathrm{kg}$ seeds at the time of sowing.

\section{Pot experiment}

The pot experiment was carried out in the pot house of Plant Pathology Division, Bangladesh Agricultural 
Research Institute (BARI), Joydebpur, Gazipur during cropping season of 2012-2013. There were six treatments viz. (i) seed treatment with Provax 200 WP (ii) seed treatment with Trichoderma spore suspension1(spores were harvested from PDA culture and spore concentration approx. $1 \times 10^{8} / \mathrm{ml}$ ) (iii) seed treatment with Trichoderma spore suspension-2 (spores were harvested from PDB culture spore concentration approx. $1 \times 10^{8} / \mathrm{ml}$ ) (iv) soil amendment with Tricho-compost-1 (v) soil amendment with Tricho-compost-2 and (vi) untreated control. The pot experiment was conducted in completely randomized design (CRD) with 5 replications. The sterilized pot soil was inoculated with the $S$. rolfsii colonized substrates at $20 \mathrm{~g} / \mathrm{kg}$ soil. Inoculated soil was incubated for 10 days maintaining proper soil moisture then the soil was amended with Tricho-compost at $100 \mathrm{~g} / \mathrm{kg}$ soil and kept for 7 days with proper soil moisture. One hundred seeds of wheat var. BARI Gom 26 were sown in each pot (size $20 \mathrm{~cm}$ ) and allowed to emerge the seedlings under congenial environment in the pot house.

\section{Field experiment}

The field trials were conducted in the fields of Plant Pathology Division, BARI, Gazipur during 2013-14, 2014-15 and 2015-16 cropping years. The treatment combination were similar as used in the pot experiment such as (i) Seed treatment with Provax 200 WP (ii) Seed treatment with Trichoderma spore suspension-1 (iii) Seed treatment with Trichoderma spore suspension-2 (iv) Soil amendment with Tricho-compost-1 (v) Soil amendment with Tricho-compost-2 and (vi) Untreated control. The field experiments were laid out in randomized complete block design (RCBD) with 3 replications. The unit plot size was $2.5 \mathrm{~m} \times 3 \mathrm{~m}$. The field soil was inoculated with $S$. rolfsii colonized substrate consisting of khesari bran, wheat bran and MOC at $100 \mathrm{~g} / \mathrm{m}^{2}$ of soil and allowed the pathogen establishment in the soil for 10 days before seed sowing. The field soil was again treated with the Tricho-compost at 3t/ha and kept for 7 days. The seeds of wheat were sown at $120 \mathrm{~kg} \mathrm{ha}^{-1}$ in the experimental plots maintaining row to row distance of $20 \mathrm{~cm}$. Proper intercultural operations were done for better growth of wheat in the field. Additional plant protecting chemicals (insecticides or fungicides) were not applied in the field.

\section{Determination of foot and root rot disease}

The experimental plot was inspected routinely to observe the foot and root rot disease on plant. In case of complexity to identify the disease, symptoms-bearing plants were collected from the field using polythene bag and brought to the Plant Pathology Laboratory, BARI. From the infected plants, the fungi were isolated following tissue planting methods [23]. After incubation, the fungi that grew over PDA were purified by the hyphal tip culture method. The isolated fungi were identified as $S$. rolfsii according to reference mycology books and manuals [24, 25]. The pure cultures of the fungi were preserved in PDA slants at $4^{\circ} \mathrm{C}$ in the refrigerator as stock culture for future use.

\section{Data collection and analysis}

Data on different parameters viz., germination, postemergence seedling mortality, shoot length, root length, shoot weight, root weight, yield of wheat were taken. Data were analysis by using MSTATC program following ANOVA. Treatment means computed using least significant difference (LSD) test.

\section{Results}

The effect of $T$. harzianum used as seed treatment by its spore suspension (Tricho-inocula) and its mass culture in compost materials called Tricho-composts for the management of foot and root rot disease of wheat caused by $S$. rolfsii was tested in the plastic tray as well as in the field experiments during the period from 2012-13 to 2015-16. The results of one pot experiment and three field experiments were discussed individually.

\section{Efficacy of Tricho-compost, T. harzianum inocula and Provax on seedling emergence, post-emergence seedling mortality and growth of wheat in pot}

The results obtained for the plastic tray/soil experiment are given in Table 1. Data showed that foot and root rot disease incidence, seed germination and growth of plants were significantly influenced by the application of $T$. harzianum in soil (Table 1). The maximum seedling mortality (11.96\%) was recorded in untreated control tray and comparatively lower seedling mortality was recorded from Tricho-composts, Tricho-inocula and Provax 200 WP treated trays. The reduction of seedling 
Table 1. Effect of T. harzianum based Tricho-compost on reduction of seedling mortality and growth of wheat under plastic tray culture conditions during 2012-2013.

\begin{tabular}{lcccccc}
\hline \multicolumn{1}{c}{ Treatments } & $\begin{array}{c}\text { Germination } \\
(\%)\end{array}$ & $\begin{array}{c}\text { Seedling } \\
\text { mortality } \\
(\%)\end{array}$ & $\begin{array}{c}\text { Reduction of seed- } \\
\text { ling mortality over } \\
\text { control }(\%)\end{array}$ & $\begin{array}{c}\text { Shoot length } \\
(\mathrm{cm})\end{array}$ & $\begin{array}{c}\text { Fresh shoot } \\
\text { weight } \\
\left(\mathrm{g} / \text { plant }^{-1}\right)\end{array}$ & $\begin{array}{c}\text { Dry shoot } \\
\text { weight } \\
\left(\mathrm{g} / \mathrm{plant}^{-1}\right)\end{array}$ \\
\hline Seed treatment with Provax & 91.50 & 2.52 & 78.93 & $40.51 \mathrm{abc}$ & $2.69 \mathrm{bc}$ & $1.31 \mathrm{c}$ \\
Seed treatment with Tricho-inocola-1 & 90.00 & 4.45 & 62.79 & $41.02 \mathrm{bc}$ & $2.41 \mathrm{c}$ & $1.11 \mathrm{~d}$ \\
Seed treatment with Tricho-inocola-2 & 82.25 & 6.07 & 49.25 & $39.37 \mathrm{c}$ & $2.30 \mathrm{~cd}$ & $1.06 \mathrm{~d}$ \\
Soil amendment with Tricho-compost-1 & 92.25 & 2.21 & 81.52 & $41.90 \mathrm{ab}$ & $3.01 \mathrm{~b}$ & $1.49 \mathrm{~b}$ \\
Soil amendment with Tricho-compost-2 & 91.00 & 2.49 & 79.18 & $42.91 \mathrm{a}$ & $3.46 \mathrm{a}$ & $1.66 \mathrm{a}$ \\
Untreated control & 82.00 & 11.96 & - & $36.84 \mathrm{~d}$ & $1.88 \mathrm{~d}$ & $0.98 \mathrm{~d}$ \\
\hline
\end{tabular}

Values in a column having same letter did not differ significantly $(p=0.05)$ by LSD.

mortality range from $49.25 \%$ to $81.52 \%$ by the application of different formulations of $T$. harzianum and Provax 200 WP compared to untreated control. The highest shoot length, fresh and dry shoot weight of wheat seedlings were recorded from Tricho-compost-2 treatment followed by Tricho-compost-1, seed treatment with Provax and Tricho-inocula. The lowest shoot length, fresh and dry shoot weight of wheat seedlings were recorded from untreated control.

\section{Effect of Tricho-compost, T. harzianum inocula and Provax} on the shoot growth and shoot weight of wheat in the field

Shoot height and shoot weight of wheat seedlings were significantly influenced by application of formulated $T$. harzianum and provax in all the years (Table 2). In 2013-14 cropping year, all the treatments gave significantly higher shoot height whereas the lowest shoot height was recorded from untreated control (Table 2). More or less similar results were also observed during 2015-16 cropping year. During 2013-14 cropping year, soil amendment with Tricho-compost- 2 gave the highest shoot height followed by Tricho-compost-1, seed treatment with Provax $200 \mathrm{WP}$ and T. harzianum inocula and the lowest shoot height was recorded from untreated control. More or less similar trend was also observed in the case of shoot weight during three consecutive cropping years where the highest shoot weight was recorded due to soil amendment with Tricho-compost-2 followed by Tricho-compost-1, seed treatment with Provax 200 WP and T. harzianum inocula and the lowest shoot weight was recorded from untreated control (Table 2).

\section{Effect of Tricho-compost, T. harzianum inocula and Provax on the root growth and root weight of wheat}

Root length and root weight of wheat were significantly increased by soil amendment with different formulation of $T$. harzianum and seed treatment with Provax $200 \mathrm{WP}$ as compared to untreated control during 2013-14, 2014-15 and 2015-16 cropping years (Table 3). Among the treatments, soil amendments with Tricho-

Table 2. Effect of $T$. harzianum on shoot growth of wheat under Sclerotium rolfsii inoculated field soils during three consecutive years.

\begin{tabular}{|c|c|c|c|c|c|c|}
\hline \multirow[t]{2}{*}{ Treatments } & \multicolumn{3}{|c|}{$\begin{array}{l}\text { Wheat shoot height during three } \\
\text { consecutive years }(\mathrm{cm})\end{array}$} & \multicolumn{3}{|c|}{$\begin{array}{l}\text { Wheat shoot weight during three } \\
\text { consecutive years ( } \mathrm{g} / \text { plant }^{-1} \text { ) }\end{array}$} \\
\hline & 2013-14 & $2014-15$ & 2015-16 & 2013-14 & $2014-15$ & 2015-16 \\
\hline Seed treatment with Provax & $50.93 \mathrm{a}$ & $51.70 \mathrm{bc}$ & $49.67 \mathrm{a}$ & $4.40 \mathrm{~b}$ & $4.68 \mathrm{bc}$ & $6.30 \mathrm{bc}$ \\
\hline Seed treatment with Tricho-inocola-1 & $51.60 \mathrm{a}$ & 44.23 de & $49.60 \mathrm{a}$ & $4.73 \mathrm{ab}$ & $5.27 \mathrm{abc}$ & $6.20 c$ \\
\hline Seed treatment with Tricho-inocola-2 & $49.60 \mathrm{a}$ & $47.17 \mathrm{~cd}$ & $51.07 \mathrm{a}$ & $5.07 \mathrm{ab}$ & $6.39 a b c$ & $7.20 \mathrm{abc}$ \\
\hline Soil amendment with Tricho-compost-1 & $52.73 \mathrm{a}$ & $54.37 \mathrm{~b}$ & $48.93 \mathrm{a}$ & $5.80 \mathrm{ab}$ & $6.20 \mathrm{ab}$ & $7.33 \mathrm{ab}$ \\
\hline Soil amendment with Tricho-compost-2 & $53.00 \mathrm{a}$ & $62.20 \mathrm{a}$ & $54.93 \mathrm{a}$ & $6.07 \mathrm{a}$ & $6.75 \mathrm{a}$ & $8.27 \mathrm{a}$ \\
\hline Untreated control & $37.60 \mathrm{~b}$ & $39.23 \mathrm{e}$ & $38.40 \mathrm{~b}$ & $3.17 \mathrm{c}$ & $3.78 \mathrm{c}$ & $4.20 \mathrm{~d}$ \\
\hline
\end{tabular}

Values in a column having same letter did not differ significantly $(p=0.05)$ by LSD. 
Table 3. Effect of $T$. harzianum on root growth of wheat under Sclerotium rolfsii inoculated field soils during three consecutive years.

\begin{tabular}{|c|c|c|c|c|c|c|}
\hline \multirow[t]{2}{*}{ Treatments } & \multicolumn{3}{|c|}{$\begin{array}{l}\text { Wheat root height during three } \\
\text { consecutive years }(\mathrm{cm})\end{array}$} & \multicolumn{3}{|c|}{$\begin{array}{l}\text { Wheat root weight during three } \\
\text { consecutive years ( } \mathrm{g} / \mathrm{plant}^{-1} \text { ) }\end{array}$} \\
\hline & 2013-14 & 2014-15 & $2015-16$ & 2013-14 & 2014-15 & 2015-16 \\
\hline Seed treatment with Provax & $7.47 \mathrm{ab}$ & $7.73 \mathrm{bc}$ & $8.07 \mathrm{a}$ & $1.27 \mathrm{ab}$ & $2.23 \mathrm{bc}$ & 1.67 \\
\hline Seed treatment with Tricho-inocola-1 & $7.20 \mathrm{ab}$ & $8.11 b c$ & $8.07 \mathrm{a}$ & $1.00 \mathrm{ab}$ & $2.27 \mathrm{bc}$ & 1.67 \\
\hline Seed treatment with Tricho-inocola-2 & $8.40 \mathrm{ab}$ & $9.27 \mathrm{ab}$ & $8.47 \mathrm{a}$ & $0.97 \mathrm{ab}$ & $2.30 \mathrm{bc}$ & 1.33 \\
\hline Soil amendment with Tricho-compost-1 & $8.47 \mathrm{ab}$ & $10.10 \mathrm{a}$ & $9.20 \mathrm{a}$ & $1.17 \mathrm{ab}$ & $2.50 \mathrm{ab}$ & 1.73 \\
\hline Soil amendment with Tricho-compost-2 & $10.67 \mathrm{a}$ & $10.07 \mathrm{a}$ & $9.27 \mathrm{a}$ & $1.40 \mathrm{a}$ & $2.70 \mathrm{a}$ & 1.87 \\
\hline Untreated control & $6.27 \mathrm{~b}$ & $6.70 \mathrm{c}$ & $5.20 \mathrm{~b}$ & $0.68 \mathrm{~b}$ & $1.90 \mathrm{C}$ & 1.07 \\
\hline
\end{tabular}

Values in a column having same letter did not differ significantly $(p=0.05)$ by LSD.

composts were found to be the better for enhancing root length and root weights of wheat over rest of the treatments. Besides, minimum root length and root weight of wheat was observed in untreated control during three consecutive cropping years.

\section{Effect of Tricho-compost, T. harzianum inocula and Provax} on the Post-Emergence seedling mortality of wheat

Seedling mortality of wheat was sharply reduced by the soil amendment with Tricho-composts, seed treatment with Tricho-inocula and Provax 200 WP (Table 4). The highest seedling mortality 23.00\%, 41.00 and $19.67 \%$ in the first year, second year and third year, respectively was recorded in the untreated control plot.
Lower seedling mortality range from $7.00-14.00 \%$ in first year, 11.67-20.67 in second year and 3.67-6.33\% in the third year was recorded due to the soil amendment with Tricho-composts and seed treatment with Trichoinocula and Provax 200 WP. The reduction of seedling mortality was ranged from $39.13-69.56 \%$ in first year, $49.59-71.54 \%$ in second year and $67.82-81.34 \%$ in third years due to various treatments as compared to untreated control.

\section{Effect of Tricho-compost, T. harzianum inocula and Provax on the yield of wheat}

The yield of wheat was significantly increased due to T. harzianum and Provax 200 WP (Table 5). The yield of

Table 4. Effect of T. harzianum on the reduction of wheat seedling mortality under Sclerotium rolfsii inoculated field soils during three consecutive years.

\begin{tabular}{|c|c|c|c|c|c|c|}
\hline \multirow[t]{2}{*}{ Treatments } & \multicolumn{3}{|c|}{$\begin{array}{c}\text { Seedling mortality during three consecutive } \\
\text { years }(\%)\end{array}$} & \multicolumn{3}{|c|}{$\begin{array}{c}\text { Reduction of seedling mortality } \\
\text { over control (\%) }\end{array}$} \\
\hline & 2013-14 & $2014-15$ & $2015-16$ & 2013-14 & 2014-15 & $2015-16$ \\
\hline Seed treatment with Provax & $\begin{array}{l}7.00 \mathrm{c} \\
(15.36)\end{array}$ & $\begin{array}{l}15.00 \mathrm{~b} \\
(22.76)\end{array}$ & $\begin{array}{l}5.00 \mathrm{~b} \\
(12.81)\end{array}$ & 69.56 & 63.41 & 74.58 \\
\hline Seed treatment with Tricho-inocola-1 & $\begin{array}{l}13.00 \mathrm{~b} \\
(21.15)\end{array}$ & $\begin{array}{l}20.67 b \\
(26.99)\end{array}$ & $\begin{array}{l}6.33 \mathrm{~b} \\
(14.51)\end{array}$ & 43.48 & 49.59 & 67.82 \\
\hline Seed treatment with Tricho-inocola-2 & $\begin{array}{l}14.00 \mathrm{~b} \\
(21.95)\end{array}$ & $\begin{array}{l}18.67 \mathrm{bc} \\
(25.52)\end{array}$ & $\begin{array}{l}6.33 \mathrm{~b} \\
(14.44)\end{array}$ & 39.13 & 54.46 & 67.82 \\
\hline Soil amendment with Tricho-compost- 1 & $\begin{array}{l}10.00 \mathrm{bc} \\
(18.46)\end{array}$ & $\begin{array}{l}12.67 \mathrm{~d} \\
(20.82)\end{array}$ & $\begin{array}{l}3.67 \mathrm{~b} \\
(11.02)\end{array}$ & 56.52 & 69.10 & 81.34 \\
\hline Soil amendment with Tricho-compost-2 & $\begin{array}{l}9.00 \mathrm{bc} \\
(17.47)\end{array}$ & $\begin{array}{l}11.67 d \\
(19.87)\end{array}$ & $\begin{array}{l}5.00 \mathrm{~b} \\
(11.15)\end{array}$ & 60.87 & 71.54 & 74.58 \\
\hline Untreated Control & $\begin{array}{l}23.00 \mathrm{a} \\
(28.68)\end{array}$ & $\begin{array}{l}41.00 \mathrm{a} \\
(39.79)\end{array}$ & $\begin{array}{l}19.67 \mathrm{a} \\
(26.26)\end{array}$ & - & - & - \\
\hline
\end{tabular}

Values in a column having same letter did not differ significantly $(p=0.05)$ by LSD; values within the parentheses were the Arcsine Transformed value. 
Table 5. Effect of T. harzianum on the yield of wheat under Sclerotium rolfsii inoculated field soils during three consecutive years.

\begin{tabular}{|c|c|c|c|c|c|c|}
\hline \multirow{2}{*}{ Treatments } & \multicolumn{3}{|c|}{ Wheat yield during three consecutive years $\left(\mathrm{t} / \mathrm{ha}^{-1}\right)$} & \multicolumn{3}{|c|}{ Yield increased over control (\%) } \\
\hline & 2013-14 & 2014-15 & $2015-16$ & 2013-14 & 2014-15 & $2015-16$ \\
\hline Seed treatment with Provax & $3.67 \mathrm{bc}$ & $3.95 \mathrm{ab}$ & $4.09 \mathrm{bc}$ & 16.08 & 17.72 & 24.94 \\
\hline Seed treatment with Tricho-inocola- 1 & $3.50 \mathrm{c}$ & $3.78 \mathrm{~b}$ & $3.99 \mathrm{c}$ & 12.00 & 14.02 & 23.06 \\
\hline Seed treatment with Tricho-inocola-2 & $3.42 \mathrm{c}$ & $3.82 \mathrm{ab}$ & $3.83 \mathrm{c}$ & 9.94 & 14.92 & 19.84 \\
\hline Soil amendment with Tricho-compost-1 & $3.83 \mathrm{~b}$ & $4.31 \mathrm{ab}$ & $4.53 \mathrm{ab}$ & 19.58 & 24.59 & 32.23 \\
\hline Soil amendment with Tricho-compost- 2 & $4.42 \mathrm{a}$ & $4.37 a$ & $4.74 \mathrm{a}$ & 30.32 & 25.63 & 35.23 \\
\hline Untreated Control & $3.08 \mathrm{~d}$ & $3.25 \mathrm{c}$ & $3.07 \mathrm{~d}$ & - & - & - \\
\hline
\end{tabular}

Values in a column having same letter did not differ significantly $(p=0.05)$ by LSD.

wheat ranged from 3.42 to $4.42 \mathrm{t}^{-\mathrm{ha}^{-1}}$ in the first year, 3.78 to $4.37 \mathrm{t} / \mathrm{ha}^{-1}$ in the second year and 3.83 to 4.74 $\mathrm{t}^{\mathrm{h}} \mathrm{ha}^{-1}$ in the third year. Among the treatment, soil amendment with Tricho-compost-2 gave the highest yield by $4.42 \mathrm{t} / \mathrm{ha}^{-1}$ in the first year, $4.37 \mathrm{t} / \mathrm{ha}^{-1}$ in the second year and $4.74 \mathrm{t} / \mathrm{ha}^{-1}$ in the third year followed by soil amendment with Tricho-compost-1, seed treatment with Provax $200 \mathrm{WP}$, seed treatment with Tricho-inocula 2 and Tricho-inocula 1. The lowest yield of wheat was recorded from the untreated control plot by $3.08 \mathrm{t} / \mathrm{ha}^{-1}$, $3.25 \mathrm{t} / \mathrm{ha}^{-1}$ and $3.07 \mathrm{t} / \mathrm{ha}^{-1}$ in the first year, second year and third year, respectively. Soil amendment with Tricho-compost-2 gave $30.32 \%, 25.63 \%$ and $35.23 \%$ higher yield in the $1^{\text {st }}$ year, $2^{\text {nd }}$ year and $3^{\text {rd }}$ year, respectively compared to control where as it was $19.58 \%$, $24.59 \%$ and $32.23 \%$ in the $1^{\text {st }}$ year, $2^{\text {nd }}$ year and $3^{\text {rd }}$ year, respectively due to application of Tricho-compost-1. Seed treatments with Provax gave 16.08\%, 17.72\% and $24.94 \%$ in the $1^{\text {st }}$ year, $2^{\text {nd }}$ year and $3^{\text {rd }}$ year, respectively higher yield of wheat than control where it was $12.00 \%$, $14.02 \%$ and $23.06 \%$ in the $1^{\text {st }}$ year, $2^{\text {nd }}$ year and $3^{\text {rd }}$ year, respectively higher by seed treatment with Tricho-inocula 1 compared to control. Therefore, considering the reduction of seedling mortality and enhancing the yield of wheat, the effect of Tricho-composts was seemed to be superior over Tricho-inocula and Provax-200WP.

\section{Discussion}

Soil borne plant pathogenic fungi especially $S$. rolfsii causing foot and root rot/seedling blight disease of many crops is a widespread problem and the use of chemicals is hardly successful. However, the high cost associated with the use of fungicides to control this disease is a limiting factor in the profitability of crop production.
According to this study, biological control, especially the Trichoderma that are common saprophytic fungi found in almost all agricultural soil and rhizosphere micro flora, have been investigated as potential bio-control agents because of their ability to reduce the disease incidence caused by plant pathogenic fungi, particularly many common soil borne plant pathogens [26-31], although some have been occasionally recorded as plant pathogens [32]. The use of Trichoderma as a biological agent for the management plant diseases had long been known [33] but its potentiality in Bangladesh agriculture was yet been explored. Therefore, soil amendment with Trichoderma based Tricho-composts and seed treatment with Trichoderma inocula were evaluated against foot and root rot disease of wheat in the pot house as well as in the field of Plant Pathology Division at BARI, Gazipur, Bangladesh. Results from the studies proved that $T$. harzianum mass cultured on compost materials could be useful for the management of foot and root rot disease of wheat caused by soil borne pathogen $S$. rolfsii.

Synthetic media are costly for mass production of $T$. harzianum. Therefore organic substrates such as rice bran, wheat bran and their integration with mustard oilcake were used for mass production of T. harzianum and it is useful for large scale production of T. harzianum based compost for soil amendment. Rini and Sulochana [34] reported that locally available organic media viz., coir pith, cow dung, poultry manure and neem cake are the excellent sources of nutrition for antagonistic fungi like T. harzianum and T. viride Besides, cow dung and neem cake mixture was reported as a recommended practice for field multiplication of Trichoderma [35].

Seedling mortality of wheat due to foot and root rot disease caused by $S$. rolfsii was reduced by soil amend- 
ments with Tricho-compost and seed treatment with Trichoderma inocula and Provax 200 WP. The findings of Deshmukh and Raut [36], Xu et al. [37], Askew and Laing [38], Uzun [39] and Younis [40] indicated that Trichoderma isolates potentially reduced the disease caused by phtyopathogenic fungi such as $R$. solani, $F$. oxysporum and $S$. rolfsii.

The results of the present study clearly indicated that Tricho-compost having potential biological control agent T. harzianum enhanced plant growth with higher grain yield of wheat. Several researchers reported that application of Trichoderma resulted in higher shoot length, root length, and shoot weight of vegetable seedlings [4143]. Soil and foliar application of T. harzianum reduced the population of soil-borne phytopathogens, especially S. rolfsii, F. oxysporum, Rhizoctonia solani and S. sclerotiorum [44, 45]. In the present study inhibition of seedling disease by Trichoderma was recorded. Different workers reported the antagonistic activity of Trichoderma isolates against different phtyopathogenic fungi such as R. solani, F. oxysporum and S. rolfsii [36-38]. Different mechanism are said to be involved i.e. competition, production of antibiotics, inhibiting fungal growth by producing volatile and non-volatile compounds as reported by Michrina et al. [46] and Calistru et al. [47]. Thus it was revealed from the study that soil amendment with Tricho-compost was most effective option for reducing seedling mortality and increasing plant growth as well as for higher yield of wheat. The other options were seed treatment with chemical fungicide Provax200WP or T. harzianum inocula for reducing seedling mortality and higher yield of wheat. This finding is also supported by many researchers [48-50]. Therefore, it may be concluded that soil amendment with Tricho-compost is the best treatment followed by seed treatment with chemical fungicide Provax and seed treatment with Trichoderma inocula for reducing seedling disease caused by $S$. rolfsii and increasing plant growth and yield of wheat.

\section{Acknowledgment}

The authors thankfully acknowledged to Bangladesh Agricultural Research Institute, Gazipur to provide financial support and logistic support for the pieces of research. Thanks go to Mr. Md. Abdur Razzak and Mr. Zamil Akter (Scientific Assistant) for their assistance for successfully complete the research in the field.

\section{Conflict of Interest}

The authors have no financial conflicts of interest to declare.

\section{References}

1. BBS. 2012. Statistical Year Book of Bangladesh. Bangladesh Bureau of Statistics (BBS), pp.156. Ministry of planning, Dhaka, Bangladesh.

2. Ahmed HU. 1986. Prevailing Wheat Diseases in Bangladesh. In: Third National Wheat Training Workshop (Edt. Anonymous), pp.124-134. Wheat Research Centre, BARl, Joydebpur, Gazipur.

3. Alam KB, Saha NK. 1991. Helminthosporium leaf blight of wheat- $a$ new problem of Bangladesh. A paper presented at the CIMMYT regional workshop on Helminthosporium leaf blight, December 2-3, 1991, pp.12, Kathmandu, Nepal.

4. Harman G. 1992. Development and benefits of rhizosphere competent fungi for biological control of plant pathogens. J. Plant Nutr. 15: 835-843.

5. Mao W, Lewis J, Hebber P, Lumsden R. 1997. Seed treatment with a fungal or a bacterial antagonist for reducing corn damping-off caused by species of Pythium and Fusarium. Plant Dis. 81: 450454.

6. Daamen R, Wijnands F, van der Vilet G. 1989. Epidemics of diseases and pest of winter wheat at different levels of agrochemical impute. J. Phytopathol. 125: 305-319.

7. Harman GE. 2011. Multifunctional fungal plant symbionts: new tools to enhance plant growth and Productivity. New Phytologist Commentry, Forum (3): 647-649.

8. Singh BN, Singh A, Singh SP, Singh HB. 2011. Trichoderma harzianum-mediated reprogramming of oxidative stress response in root apoplast of sunflower enhances defense against Rhizoctonia solani. Eur. J. Phytopathol 131: 121-134.

9. Benitez T, Rincon AM, Limon MC, Codon AC. 2004. Biocontrol mechanisms of Trichoderma strains, a review article. Intl. Microbiol. 7: 249-260.

10. Goes LB, Lima da Costa AB, Freire LLC, Oliveria NT. 2002. Randomly Amplified Polymorphic DNA of Trichoderma Isolates and Antagonism Against Rhizoctonia solani. Braz. Arch. Biol. Technol. 45: 254-257.

11. Narayan S, Lata KP, Kotasthane AS. 2006. Genetic relatedness among Trichoderma isolates inhibiting a pathogenic fungi Rhizoctonia solani, Afr. J. Biotechnol. 5: 580-584.

12. Kucuk C, Kivanc M. 2004. In vitro antifungal activity of strains of Trichoderma harzianum. Turk. J. Biol. 28: 111-115.

13. Hasan MM, Alam S. 2007. Efficacy of Trichoderma harzianum treated seeds on field emergence, seedling disease, leaf blight severity and yield of wheat cv. Gourab and Shourav under field condition. Intl. J. Boi-Res. 3: 23-30.

14. Vann S. 2011. University of Arkansas, Division of Agriculture, Cooperative Extension Service, USA. http://www.uaex.edu.

15. Whipps JM, Lumsden RD. 2001. Commercial use of fungi as plant disease biological control agents: Status and prospects. pp. 9-22 in: 
Fungi as Biocontrol Agents: Progress, Problems and Potential. T. M. Butt, C. Jackson, and N. Magan, eds. CABI Publishing, Wallingford, UK

16. Harman GE, Howell CR, Viterbo A, Chet I, Lorito M. 2004. Trichoderma species opportunistic, avirulent plant symbionts. Nat. Rev. Microbiol. 2: 43-56.

17. Harman GE. 2006. Overview of mechanisms and uses of Trichoderma spp. Phytopathology 96: 190-194.

18. Singh A, Srivastava S, Singh HB. 2007. Effect of substrates on the growth and shelf life of Trichoderma harzianum and its use in biocontrol of diseases. Bioresour. Technol. 98: 470-473.

19. Das BC, Roy SK, Bora LC. 1997. Mass multiplication of Trichoderma species on different media. J. Agril. Sci. Society of North East India 10: 95-100.

20. Shamsuzzaman SM, Islam A, Hossain I. 2003. Trichoderma culture and germination of sweet gourd seed. Bangladesh J. Seed Sci. and Tech. 7: 91-95.

21. Rettinassabababy C, Ramadoss N. 2000. Effect of different substrates on the growth and sporulation of Trichoderma viride native isolated. Agril. Sci. Digest. 20: 150-152.

22. Cotxarrera L, Trillas-Gay MI, Steinberg C, Alabouvette C. 2002. Use of sewage sludge compost and Trichoderma asperellum isolates to suppress Fusarium wilt of tomato. Soil Biol. Biochem. 34: 467-476.

23. Baxter AP, Rong IH, Roux C, Van der Linde EJ.1999. Collecting and Preserving Fungi-A Manual for Mycology. Plant Protection Research Institute. Private Bag X134, Pretoria, 0001 South Africa.

24. Barnett HL, Hunter BB. 1972. Illustrated Genera of Imperfect Fungi. 3rd Ed. Burges Co., Minneapolis, USA.

25. Booth C. 1971. The Genus Fusarium. pp.237. Commonwealth Mycology Institute Kew, Survey, England.

26. Papavizas GC. 1985. Trichoderma and Gliocladium: Biology, ecology and potential for biocontrol. Annu. Rev. Phytopathol. 23: 23-54.

27. Sivan A, Chet I. 1986. Biological control of Fusarium spp. in cotton, Wheat and muskmelon by Trichoderma harzianum. J. Phytopathol. 116: 39-47.

28. Spiegel Y, Chet I. 1998. Evaluation of Trichoderma spp. as biocontrol agent against soil borne fungi and plant parasitic nematodes In Israel. Integr. Pest Manage. Rev. 3: 169-175.

29. Freeman S, Minz D, Kolesnik I, Barbul O, Zreibil A, Maymon M, et al. 2004. Trichoderma biocontrol of Colletotrichum acutatum and Botrytis cinerea, and survival in strawberry. Eur. J. Plant Pathol. 110: 361-370.

30. Ashrafizadeh A, Etebarian HR, Zamanizadeh HR. 2005. Evaluation of Trichoderma isolates for biocontrol of Fusarium wilt of melon. Iranian. J. Phytopathol. 41: 39-57.

31. Dubey SC, Suresh M, Singh B. 2007. Evaluation of Trichoderma species against Fusarium oxysporum fsp. Ciceris for integrated management of chickpea wilt. Biol. Contr. 40: 118-127.

32. Menzies JG. 1993. A strain of Trichoderma viride pathogenic to germinating seedlings of cucumber, pepper and tomato. Plant Pathol. 42: 784-791.

33. Tran TT. 1998. Antagonistic effectiveness of Trichoderma against plant fungal pathogens. Plant Protection. 4: 35-38.
34. Rini CR, Sulochana KK. 2007. Substrate evaluation for multiplication of Trichoderma spp. J. Trop. Agric. 45: 58-60.

35. KAU. 2002. pp.278, Package of Practices Recommendations: Crops. Twelfth edition. Directorate of Extension, Kerala Agricultural University, Thrissur.

36. Deshmukh PP, Raut JG. 1992. Antagonism by Trichoderma spp. on five plant pathogenic fungi. New Agriculturist. 3: 127-130.

37. Xu T, Zhong JP, Li DB. 1993. Antagonism of T. harzianum T82 and Trichoderma species NF9 against soil and seed borne pathogens. Acta phytopathologica Sinica 23: 63-67.

38. Askew DJ, Laing MD. 1994. The in-vitro screening of Trichoderma isolates for antagonism to Rhizoctonia solani and an evaluation of different environmental sites of Trichoderma as sources of aggressive strains. Plant and Soil. 159: 227-281.

39. Uzun I. 2004. Use of spent mushroom compost in sustainable fruit production. J. Fruit Ornam. Plant Res. 12: 157-165.

40. Younis NA. 2005. Mycoparasitism of Trichoderma harzianum and Trichoderma longibrachiatum on Fusarium oxysporum f.sp. phaseoli the causal of bean wilt disease. Bull. Faculty Agric. Cairo Univ. 56: 201-219.

41. Hossain I, Shamsuzzaman SM. 2003. Developing Trichoderma based bio-fungicide using agro-waste. BAU Res. Prog. 14: 49-50.

42. Hossain I, Naznin MHA. 2005. BAU biofungicide in controlling seedling disease of some summer vegetables. BAU Res. Progr. 15: 32-35.

43. Shaban WI, El-Bramawy MA. 2011. Impact of dual inoculation with Rhizobium and Trichoderma on damping off, root rot diseases and plant growth parameters of some legumes field crop under greenhouse conditions. Int. Res. J. Agric. Sci. Soil Sci. 1: 98-108.

44. Sivasithamparam K, Ghisalberti EL. 1998. Trichoderma and Gliocladium. pp. 139-191. (C. P. Kubicek, G. E., eds.). Vol. 1. Taylor and Francis, London.

45. Hoitink HAJ, Boehm MJ. 1999. Biocontrol within the context of soil microbial communities: a sub-strate-dependent phenomenon. Annu. Rev. Phytopathol. 37: 427-446.

46. Michrina J, Michalikova A, Rohaic T, Kulichova R. 1995. Antibiosis as a possible mechanism of antagonistic action of $T$. harzianum against $F$. culmorum. Ochrana-Rostlin. 31:177-184.

47. Calistru C, Mclean M, Berjak P. 1997. In-vitro studies on the potential for biological control of Aspergillus flavus and Fusarium moniliforme by Trichoderma species; A study of the production of extracelluar metabolites by Trichoderma species. Mycopathologia 137: 115-124.

48. Hannan MA, Hasan MM, Hossain I, Rahman SME, Ismail AM, Oh DH. 2012. Integrated Management of Foot Rot of Lentil Using Biocontrol Agents under Field Condition. J. Microbiol. Biotechnol. 22: 883-888.

49. Devi HJ, Maity TK, Paria NC. 2003. Effect of different sources of nitrogen on yield and economics of cabbage. Environ. Ecol. 21: 878-880.

50. Sultana N, Hossain I. 1999. Biological control of foot and root rot of lentil with Ttrichoderma harzianum. Bangladesh J. Seed Sci. Tech. 3: 107-111. 